\title{
Influence of Teacher Competence, Motivation and Job Satisfaction on Teacher's Performance SMP Negeri 1 Cikarang Bekasi Regency East
}

\author{
Niantoro Sutrisno $^{1 *}$, H. Puji Isyanto ${ }^{2}$, Rachmat Hasbullah ${ }^{3}$ \\ ${ }^{1,2,3}$ Singaperbangsa University, Karawang, Indonesia
}

\begin{abstract}
The purpose of this study is to identify, analyze and assess influences of Teacher's Competency, Motivation and Job Satisfaction on Teacher's Performance at State Junior High School 1 East CikarangBekasi Regency.

This research is intended to giving advice for the teacher's competence, motivation and job satisfaction in order teacher's performance improve. This research was using descriptive and verification method.

Descriptive research is used to describe characteristics of a population or phenomenon being studied. Verification is the research conducted with the aim to prove the truth of a theory on a particular time and place.

The results of this research are as follows:

1. Range scale of teacher'scompetence isquite good, it need to be improved.

2. Range scale of teacher's motivation is quite high, it need to increased.

3. Range scale of teacher's job satisfaction is quite satisfied, it need to increased.

4. Range scale of Teacher's performance is quite good, it need for improved.

5. There is a relationship between teacher's competence and motivation.

6. There is a relationship between teacher's competence and job satisfaction.

7. There is a relationship between motivation and job satisfaction.

8. There are both partially and simultaneously influence teacher's competence, motivation and job satisfaction on teacher's performance.
\end{abstract}

Keywords: Job Satisfaction, Motivation, Teacher's Competency, Teacher's Performance

\section{INTRODUCTION}

One of the suppressions in the 1945 Constitution of Indonesia is to enrich the life of the nation. Technically the National Education System Act no. 20 year 2003 Article 3 states that national education has a function for developing and shaping the character and civilization of a nation that is dignified in order to enrich the life of the nation, whose purpose is to develop the potential of students to become humans that are faithful and righteous to The One Almighty God, noble, healthy, scholarly, intelligent, creative, independent and become citizens that are democratic and responsible. Supardi (2013:7) states that the success of a nation's education is very determined by teachers.

* Corresponding author. Email address: torrosoet@gmail.com 
Teacher performance is the competence of a teacher in implementing learning and responsible for students under their guiandce by increasing the learning achievements of the students. It is stated by Supardi (2013:55) that teacher performance is able to be seen clearly in learning.

Andrew Ragatz et. al. in the publication of the Ministry of Education and World Bank publication no 53732-ID (2010:2) states that low performance in the world of education is one of them caused by the low performance of teaching labor. It is not surprising that with the low performance of teaching labor or teachers there is an impact to the results of students such as what is stated in the report of Jalal et. al. (2009:5) publication no.48578 that is arranged by the Ministry of Education and the World Bank shows that education results in Indonesia for the 8th grade or in the junior high school level is placed in a low ranking below international average, compared with other countries in the learning subjects of mathematics and science.

The performance that is not optimal is able to be caused by several factors among others are Ability, Motivation and, Job Satisfaction where the mentioned three factors become parts from this research. Competence becomes an important element for curriculum implementation in the class. A good curriculum without the support of teacher competence will not have a positive impact to performance such as summarized in the research results of Rohimah (2013) that competence has an impact to performance.

Teachers that have job motivation will show optimal performance such as summarized from the research results of Devi (2009). A characteristic of a teacher that is motivated is a teacher that is disciplined at job. Discipline at job is marked by job attenandce in accorandce with what is determined.

Hadiyatmo (2012) in his research states that job satisfaction will impact performance.

A good performance will be reached if teachers feel satisfaction in job such as stated by Wibisono (2011: 138) that employee satisfaction is an important matter and directly proportional with their contribution to the corporation.

\section{LITERATURE STUDY}

\section{Teacher Competence}

Teacher competence is defined according the Ministry Regulation above Chapter II Article 3 Clause (1) which is stated that:

"Competences meant in Article 2 is a set of knowledge, skill, and behavior that has to be possessed, internalized, mastered, and actualized by teachers in implementing professional tasks".

As for the competence that teachers have to possess according to the same act in Chapter II Article 3 clause (2) it is stated that teacher competences meant in clause (1) consists of pedagogic ability, personality ability, social ability, and professional competence that are obtained through profession education.

\section{Teacher Competence Dimensions}

As explained in the paragraph before that teacher competence consists of pedagogic competence, personality competence, social competence, and professional competence. Teacher competence dimensions according to 
Government Regulation of the Republic of Indonesia Number 74 Year 2008 About Teachers Chapter I Article 1, consists of:

1. Pedagogic Competence Dimension

2. Personality Competence

3. Social Competence

4. Professional Competence

\section{Motivation}

Bangun (2012:312) defines motivation as the following:

"Motivation comes from the word motive, which means push. Therefore motivation means a condition that pushes or becomes a cause a person does an act/activity that happens consciously".

Ivansevich, Konopaske and Matteson $(2005 ; 143)$, states that there is no person that doubts the primary role of motivation in shaping behavior, and specifically in influencing job performance in organizations. Furthermore Ivansevich, Konopaske, and Matteson (2005: 148) one of the important approaches in motivation is the theory that is stated by Mclelland.

\section{Motivation Dimensions}

According to Nasution (2000:205), McClelland has proposed a motivation theory that closely relates with the learning concept. He is confident that most needs come from culture. Three of the needs that are studied are the need for achievement, need for affiliation, and need for power.

\section{Job Satisfaction}

With job satisfaction an employee is able to feel if his/her job is pleasing or not pleasing to be done. Dermawan Wibisono $(2011 ; 138)$ states that employee satisfaction becomes one of the important factors and is directly proportional with their contribution to the corporation. That will increase the efficiency and effectiveness of the corporation that implicates to the corporation's performance increase

Robbins $(2001 ; 139)$ defines job satisfaction as the following:

"Referring to the general attitude of an individual to his/her job. Somebody with a high job satisfaction level shows a positive attitude to that job; somebody that is not satisfied with his/her job shows a negative attitude to his/her job. If people speak about employee attitude, more often they mean job satisfaction".

\section{Job Satisfaction Dimensions}

For knowing that employees feel satisfied, the dimensions have to be known. Robbins (2001; 149) explains factors that determine job satisfaction as the following:

1. Jobs That Are Mentally Challenging

2. Rewards That Are Worth It

3. Supportive Job Condition

4. Supportive Co-Workers

5. Conformity Between Personality-Job

\section{Teacher Performance}

In an operational level, teachers are a determinant of education success through their performance in the institutional, instructional, and experiential levels 
Teachers are human resources that are able to leverage other factors so excellent learning is created and become a primary factor that determines education.

According to Husdarta in Supardi (2013:54) teacher performance in learning becomes the most important part in supporting the creation of the education process effectively especially in developing a disciplinary attitude and quality as a result of the learning of students.

Teacher performance is the ability of a teacher in implementing the learning task and responsible for students under their guiandce by increasing the learning achievements of the students. Because of that, teacher performance is able to be defined as a condition that shows the ability of a teacher in implementing their tasks and illustrates the presence of an act that teachers show in or as long as implementing the learning activity.

\section{Teacher Performance Dimensions}

Teacher performance dimensions impliedly is in the Acts of the Republic of Indonesia Number 14 Year 2005 About Teachers and Lecturers Chapter IV Article 20 clause (a) namely in implementing professional tasks teachers are obliged to plan learning, implement the excellent learning process and judge and evaluate learning results.

Meanwhile Supardi (2013:23) defines teacher performance is the ability and success of teachers in implementing learning tasks that are shown by the following dimensions:

1. The ability to arrange a learning plan.

2. The ability to implement learning.

3. The ability to implement interpersonal relations.

4. The ability to implement judgment of learning results.

5. The ability to implement enrichment programs.

6. The ability to implement remedial programs.

\section{RESEARCH RESULTS AND DISCUSSION}

Based on data processing results that the competence as a whole is present in a well enough average with a score of 132 . The motivation variable recapitulation is in a high enough range with a score of 131 . The job satisfaction variable is in a satisfactory enough range with a score of 125 . The teacher performance recapitulation variable is in a well enough range with a score of 127.

Correlation Analysis and Influence of competence, motivation and job satisfaction to teacher performance in Public Junior High School 1 East Cikarang Bekasi Regency

a. Pearson Product Moment Correlation Analysis

For knowing the results of correlation analysis between competence, motivation, and job satisfaction variables to teacher performance in Public Junior High School 1 East Cikarang Bekasi Regency, it is able to be seen in table 1 below: 
Table 1

Correlation of Competence $\left(\mathbf{X}_{1}\right)$, Motivation $\left(\mathbf{X}_{2}\right)$ and Job Satisfaction $\left(\mathrm{X}_{3}\right)$

\section{Correlations}

\begin{tabular}{llrrrr}
\hline & Competence & Motivation & Job Satisfaction & Performance \\
\hline Competence & Pearson Correlation & 1 & $.443^{* *}$ & $.384^{*}$ & $.548^{* *}$ \\
& Sig. (2-tailed) & & .005 & .016 & .000 \\
& $\mathrm{~N}$ & 39 & 39 & 39 & 39 \\
\hline Motivation & Pearson Correlation & $.443^{* *}$ & 1 & $.431^{* *}$ & $.581^{* *}$ \\
& Sig. (2-tailed) & .005 & & .006 & .000 \\
& $\mathrm{~N}$ & 39 & 39 & 39 & 39 \\
\hline Job & Pearson Correlation & $.384^{*}$ & $.431^{* *}$ & 1 & $.568^{* *}$ \\
& Sig. (2-tailed) & .016 & .006 & .000 \\
& $\mathrm{~N}$ & 39 & 39 & 39 & 39 \\
\hline Performance & Pearson Correlation & $.548^{* *}$ & $.581^{* *}$ & $.568^{* *}$ & 1 \\
& Sig. (2-tailed) & .000 & .000 & .000 & 39 \\
& $\mathrm{~N}$ & 39 & 39 & 39 & 39 \\
\hline
\end{tabular}

**. Correlation is significant at the 0.01 level (2-tailed).

*. Correlation is significant at the 0.05 level (2-tailed).

Based on the table above correlation values: $\mathrm{X} 1$ correlation to $\mathrm{X} 2$ as large as 0.443 ;

$\mathrm{X} 2$ correlation to $\mathrm{X} 3$ as large as $0.431 ; \mathrm{X} 1$ correlation to $\mathrm{X} 3$ as large as 0.384 . Which means the above numbers show that there is a positive relation between the Competence (X1), Motivation (X2), and job satisfaction (X3) to teacher performance in Public Junior High School 1 East Cikarang Bekasi Regency.

b. Analysis of Competence, Motivation, and Job Satisfaction Influences to teacher performance in Public Junior High School 1 East Cikarang Bekasi Regency The recapitulation is able to be seen in table 2 below:

Table 2

Simultaneous Influence of Competence $\left(\mathrm{X}_{1}\right)$, Motivation $\left(\mathrm{X}_{2}\right)$ and Job Satisfaction $\left(\mathrm{X}_{3}\right)$ to Performance $(\mathrm{Y})$

\begin{tabular}{|c|c|c|c|c|c|c|}
\hline \multirow{2}{*}{ Variable } & \multirow{2}{*}{$\begin{array}{c}\text { Route } \\
\text { Analysis }\end{array}$} & \multirow{2}{*}{$\begin{array}{c}\text { Direct } \\
\text { Influence }\end{array}$} & \multicolumn{3}{|c|}{ Influence Through } & \multirow{2}{*}{$\%$} \\
\hline & & & $\mathrm{X} 1$ & $\mathrm{X} 2$ & X3 & \\
\hline $\begin{array}{l}\text { Competence } \\
\qquad\left(\mathrm{X}_{1}\right)\end{array}$ & 0.284 & 0.080 & - & 0.039 & 0.035 & $15 \%$ \\
\hline $\begin{array}{c}\text { Motivation } \\
\left(\mathrm{X}_{2}\right)\end{array}$ & 0.316 & 0.099 & 0.039 & - & 0.043 & $18 \%$ \\
\hline Job & & & & 0.043 & & \\
\hline $\begin{array}{l}\text { Satisfaction } \\
\left(\mathrm{X}_{3}\right)\end{array}$ & 0.323 & 0.104 & 0.035 & & - & $18 \%$ \\
\hline $\mathrm{X}_{1}, \mathrm{X}_{2}, \mathrm{X}_{3}$ & & & & & & $52 \%$ \\
\hline
\end{tabular}

Source: Processed data, 2016 
While in more detail the amount of influence is able to be seen in table 4.7 in the next Hypothesis Test.

\section{Hypothesis Test}

Based on t count test results an X1 value as large as 2.120 is obtained, $\mathrm{X} 2$ as large as 2.303 and $\mathrm{X} 3$ as large as 2.422 as written in table 3 below:

Table 3

Influence of Partial Competence $\left(\mathrm{X}_{1}\right)$, Motivation $\left(\mathrm{X}_{2}\right)$ and Job Satisfaction $\left(\mathrm{X}_{3}\right)$ to Performance $(\mathrm{Y})$

\begin{tabular}{|c|c|c|c|c|c|c|c|c|}
\hline \multicolumn{9}{|c|}{ Coefficients $^{\mathrm{a}}$} \\
\hline \multirow{2}{*}{ Model } & \multicolumn{2}{|c|}{$\begin{array}{l}\text { Unstandardized } \\
\text { Coefficients }\end{array}$} & $\begin{array}{c}\text { Standardized } \\
\text { Coefficients }\end{array}$ & \multirow{2}{*}{$\mathrm{t}$} & \multirow{2}{*}{ Sig. } & \multicolumn{3}{|c|}{ Correlations } \\
\hline & B & Std. Error & Beta & & & $\begin{array}{l}\text { Zero- } \\
\text { order }\end{array}$ & Partial & Part \\
\hline 1 (Constant) & -2.846 & 15.587 & & -.183 & .856 & & & \\
\hline Competence & .338 & .159 & .284 & 2.120 & .041 & .548 & .337 & .248 \\
\hline Motivation & .420 & .182 & .316 & 2.303 & .027 & .581 & .363 & .269 \\
\hline $\begin{array}{l}\text { Job } \\
\text { Satisfaction }\end{array}$ & .203 & .084 & .323 & 2.422 & .021 & .568 & .379 & .283 \\
\hline
\end{tabular}

a. Dependent Variable: Performance

The research hypothesis test with a two tailed test for correlation coefficients in the real standard of 5\%, compares t count and t table, obtained as the following:

$\mathrm{X} 1$ as large as $2.120>2.03 \mathrm{H} 0$ rejected, means that there is an influence of competence to performance.

$\mathrm{X} 2$ as large as $2.303>2.03 \mathrm{H} 0$ rejected, means that there is an influence of motivation to performance

$\mathrm{X} 3$ as large as $2.422>2.03 \mathrm{H} 0$ rejected, means that there is an influence of job satisfaction to performance

\section{Determination Coefficient}

The determination coefficient value to the relation between competence, motivation and job satisfaction to teacher performance in Public Junior High School 1 East Cikarang Bekasi Regency is able to be seen in the table below:

Table 4

Determination Coefficient $\left(\mathrm{R}^{2}\right) \mathrm{X}_{1}, \mathrm{X}_{2}$ and $\mathrm{X}_{3}$ To $\mathrm{Y}$

Model Summary ${ }^{\mathrm{b}}$

\begin{tabular}{lrrrr}
\hline Model & R & R Square & Adjusted R Square & $\begin{array}{c}\text { Std. Error of the } \\
\text { Estimate }\end{array}$ \\
\hline 1 & $.723^{\mathrm{a}}$ & .523 & .482 & 7.517 \\
\hline
\end{tabular}

a. Predictors: (Constant), Kepuasan Kerja, Kompetensi, Motivasi

b. Dependent Variable: Kinerja

Based on the table above the R Square value shows the determination coefficient value which is $=0.52$ or $52 \%$ which means the teacher performance variable is influenced by competence, motivation and job satisfaction variables, while the other $48 \%(100 \%-52 \%=48 \%)$ is influenced by other factors that are not studied in this research. 


\section{Significant Correlation Test}

Significant correlation values are able to be seen in the table below.

Table 5

Analysis Results of Simulant Influence of Competence $\left(\mathrm{X}_{1}\right)$, Motivation $\left(\mathrm{X}_{2}\right)$ and Job Satisfaction $\left(\mathrm{X}_{3}\right)$ to Teacher Performance $(\mathrm{Y})$

ANOVA $^{b}$

\begin{tabular}{llrrrrr}
\hline & Model & Sum of Squares & df & Mean Square & \multicolumn{1}{c}{ F } & \multicolumn{1}{c}{ Sig. } \\
\hline 1 & Regression & 2168.605 & 3 & 722.868 & 12.792 & $.000^{\mathrm{a}}$ \\
Residual & 1977.754 & 35 & 56.507 & & \\
Total & 4146.359 & 38 & & & \\
\hline
\end{tabular}

a. Predictors: (Constant), Kepuasan Kerja, Kompetensi, Motivasi

b. Dependent Variable: Kinerja

In the Anova test or F test, an F count is obtained which is 12.792 with a significance level of 0.000 . Because the probability value $(0.000)$ is less than 0.05 , competence (X 1), Motivation (X2) and job satisfaction (X3) to performance (Y).

\section{SUMMARY AND SUGGESTIONS}

The summary of this research is as the following:

1. Teacher competence has a positive and significant influence to teacher performance, so teacher performance is able to increase in line with their competence increase. Therefore the research hypothesis that states that there is an influence of competence to performance, is able to be accepted.

2. Motivation has a positive and significant influence to teacher performance, so teachers are able to increase their performance in the presence of motivation increase. Therefore the research hypothesis that states that there is an influence of motivation to performance, is able to be accepted.

3. Job satisfaction has a positive and significant influence to positive teacher performance, so teachers are able to increase their performance in the presence of job satisfaction increase. Therefore the research hypothesis that states that there is an influence of job satisfaction to performance, is able to be accepted.

4. Competence, motivation and job satisfaction simultaneously have a positive and significant influence to performance. Therefore, teacher performance is able to increase in the presence of the simultaneous increase of competence, motivation and job satisfaction.

Suggestions that the writer are able to propose are as the following:

1. Teachers have to increase their competence more by participating in several kinds of training such as Curriculum Training or Teacher Learning Subject Conference so the competence that they have is able to develop.

2. An education supervision needs to be implemented more routinely at schools, in the implementation of the supervision process a motivation presentation also has to be implemented.

3. Job satisfaction needs to be increased through job distributions that are challenging in the form of task increases. A wage increase to non- 
government employee teachers and facilitate government employee teachers that have not yet obtained certificates. Other than that, job conditions need to be improved and the relations between teachers and non-teachers have to be improved through routinely planned non formal meetings.

4. Work results that are well enough are not yet optimal, so it has to be increased through Sustainable Professional Development .

\section{References}

Armstrong, M. (2009). A Handbook of Human Resource Management Practice (10th Ed). London: Kogan Page.

Boddy, D. (2008). Management Fourth Edition. London: Pearson Education.

Bangun, W. (2012). Manajemen Sumber Daya Manusia. Jakarta: Erlangga.

Chalofsky, N.E., Rocco, T. S., \& Morris, M.L. (2014). Handbook of Human Resource Management. New Jersey: Wiley \& Sons.

Darodjat, T. (2015). Konsep-konsep Dasar Manajemen Personalia Masa Kini. Bandung: Refika Aditama.

Didik, H. (2012). Pengaruh Kompetensi, Kompensasi dan Kepuasan Kerja Terhadap Kinerja Karyawan Pada PT Ciomas Adisatwa Balikpapan.

Devi, D., \& Eva, K. (2009). Analisis Pengaruh Kepuasan Kerja dan Motivasi Terhadap Kinerja Karyawan dengan Komitmen Organisasional sebagai Variabel Intervening (Studi Pada Karyawan Outsourcing Pt Semeru Karya Buana Semarang). Semarang: Universitas Diponegoro.

Dimyati., \& Mudjiono. (2013). Belajar dan Pembelajaran. Jakarta: Rineka Cipta. Drucker, P.F. (2008). The Practice of Management. California: Harper Collins.

Ebert, R.J., \& Griffin, R.W. (2013). Business Essensials. New Jersey: Pearson.

Garis-garis Besar Haluan Negara. (1988). Ketetapan MPR No. II/MPR/1988. Jakarta.

Griffin, R.W., \&Moorhead, G. (2014). Organizational Behaviour: Managing People and Organization. Mason Ohio: South Western.

Hamzah, B.U. (2016). Teori Motivasi \& Pengukurannya, Analisis di Bidang Pendidikan. Jakarta: Bina Aksara.

Handoko, T. (2001). Manajemen Personalia dan Sumberdaya Manusia. Yogyakarta: BPFE.

Hikmat. (2011). Manajemen Pendidikan. Bandung: Pustaka Setia.

Himpunan Peraturan Perundang-undangan: Undang-undang Guru dan Dosen. (2011). Bandung: Fokus Media.

Imron, A., Maisyaroh., \& Burhanuddin. (2003). Manajemen Pendidikan: Analisis Substantif dan Aplikasinya dalam Institusi Pendidikan. Malang. Universitas Negeri Malang.

Ivansevich, J.M., Konopaske, R., \& Matteson, M,T. (2005). Perilaku dan Manajemen Organisasi. Jakarta: Erlangga.

Jalal, F., Muchlas, S., Mae, C.C., Ritchie, S., Andrew, B.R., \& Siwage D.N. (2010). Report No.48578-ID. Jakarta: Kementerian Pendidikan dan World Bank.

Koswara, D., \& Halimah. (2008). Seluk Beluk Profesi Guru. Bandung: Pribumi Mekar. 
Kondalkar, V.G. (2007). Organizational Behaviour. New Delhi: New Age International Publisher.

Keran, N., \& Kristina. (2012). Pengaruh Motivasi Kerja, Kompetensi dan Kompensasi Terhadap Kinerja Karyawan di Yayasan Bintang Timur Tangerang. Jakarta: Universitas Esa Unggul.

Khaerul, U. (2010). Perilaku Organisasi. Bandung: Pustaka Setia.

Manullang. (2012). Dasar-dasar Manajemen. Yogyakarta: Gadjah Mada University Press.

Marsana., \& Handayani. (2012). Pengaruh Kompetensi dan Motivasi Kerja Terhadap Kepuasan Kerja Serta Implikasinya Pada Kinerja Guru (Studi kasus pada SMA Negeri Se Sub Rayon Semarang). Semarang: STIE Dharma Putra.

Mathis, R.L., \& Jackson, J.H. (2011). Human Resource Management. USA: South Western.

McShane, S.L., \& Von, G., \& Mary, A. (2008). Organizational Behavior. New York: Mc Graw Hill Irwin.

Moeheriono. (2012). Pengukuran Kinerja Berbasis Kompetensi,(Edisi Revisi). Depok: Rajawali Pers.

Nasution, M. (2000). Manajemen Personalia. Jakarta: Djambatan.

Nat Cong, N., \& Van, D.N. (2013). Effect of Motivation and Job Satisfaction on Employee's Performance at Petrovietnam Nghe an Construction Joint Stock Corporation $(P V N C)$. Tra Vinh City

Narbuko, C., \& Abu, A. (2015). Metodologi Penelitian. Jakarta: Bumi Aksara.

Palan, R. (2008). Competency Management. Jakarta: PPM.

Peraturan Pemerintah Republik Indonesia Nomor 19 Tahun 2005 Tentang Standar Nasional Pendidikan. (2005). Jakarta .

Peraturan Pemerintah Republik Indonesia Nomor 74 Tahun 2008 Tentang Guru.

Ronald, L. (2010). Pengaruh Kompetensi dan Motivasi Kerja Terhadap Kinerja Karyawan PT Allianz Life Indonesia Wilayah Jawa Barat. Bandung: Universitas Komputer Indonesia.

Ragatz, A., Dandan, C., Ratna, K., Muhammad, F., Siwage, D.N., Susie, S., \& Imam, S. (2009). Report No. 53732-ID. Jakarta: Kementerian Pendidikan dan World Bank.

Riduwan., \& Engkos, A.K. Path Analysis, Analisis Jalur: Cara Menggunakan dan Memakai. Bandung: Alfabeta.

Robbins, S.P., \& Coulter, M. (2010). Manajemen (Edisi Kesepuluh, Jilid 1). Jakarta: Erlangga.

Robbins, S.P. (2001). Perilaku Organisasi. Jakarta: Prenhalindo.

Rohimah, S. (2013). Pengaruh Kompetensi, Kompensasi, Disiplin Kerja Terhadap Kinerja dan Kepuasan Kerja Guru SMA Islamic Village Karawaci Tangerang. Jakarta: Universitas Esa Unggul.

Sutrisno, E. (2014). Manajemen Sumber Daya Manusia. Jakarta: Kencana.

Suhariadi, F. (2013). Manajemen Sumber Daya Manusia, dalam Pendekatan Teoritis-Praktis. Surabaya: Airlangga University Press.

Siagian, S. (2012). Teori Motivasi dan Aplikasinya. Jakarta: Rineka Cipta.

Snell, S., \& Bohlander, G. (2013). Managing Human Resources. USA: South Western. 
Sudarmanto. (2014). Kinerja dan Pengembangan Kompetensi SDM: Teori, Dimensi Pengukuran dan Implementasi dalam Organisasi. Yogyakarta: Pustaka Pelajar.

Sugiyono. (2014). Metode Penelitian Kuantitatif Kualitatif dan $R \& D$. Bandung: Alfabeta.

Sugiyono. (2014). Metode Penelitian Bisnis. Bandung: Alfabeta.

Supardi. (2013). Kinerja Guru. Bandung: Rajawali Grafindo.

Suparmoko, M. (2009). Metode Penelitian Praktis untuk Ilmu-ilmu Sosial, Ekonomi dan Bisnis, (Edisi 4). Yogyakarta: BPFE Yogyakarta.

Suparno. (2007). Pengaruh Motivasi Kerja dan Kepemimpinan Situasional Kepala Sekolah Terhadap Kinerja Guru SMP Negeri Kecamatan Pemalang Kabupaten Pemalang. Semarang: Universitas Negeri Semarang.

Undang-undang Republik Indonesia Nomor 20 Tahun 2003 Tentang Sistem Pendidikan Indonesia. (2003). Jakarta

Undang-undang Republik Indonesia Nomor 14 Tahun 2005 Tentang Guru dan Dosen. (2005). Jakarta.

Wibisono, D. (2011). Manajemen Kinerja Korporasi dan Organisasi: Panduan Penyusunan Indikator. Jakarta: Erlangga.

Williams, K. (2012). Management a Practical Introduction. California: Mc Graw Hill.

Wijaksana, F. (2013). Statistik. Jakarta: Statistik Pendidikan.

Yuniarsih, T., \& Suwatno. (2011). Manajemen Sumber Daya Manusia: Teori, Aplikasi dan Isu Penelitian. Bandung: Alfabeta. 